\title{
Eukaryotic Elongation Factor 2 Kinase
}

National Cancer Institute

\section{Source}

National Cancer Institute. Eukaryotic Elongation Factor 2 Kinase. NCI Thesaurus. Code C119728.

Eukaryotic elong ation factor 2 kinase $(725 \mathrm{aa}, \sim 82 \mathrm{kDa}$ ) is encoded by the human EEF2K gene. This protein is involved in both the negative regulation of protein synthesis and serine/threonine protein phosphorylation. 